\title{
Chemical and isotopic characterization of nitrate retained and leached from soil after manure fertilization-by lysimeter experiments
}

\author{
Neus Otero ${ }^{1, *, 2}$, Alba Llovet $^{3,4}$, Raúl Carrey ${ }^{1}$, Angela Ribas $^{3,4}$, Xavier Domene ${ }^{3,4}$, Stefania \\ Mattana $^{4}$, Juan Chin-Pampillo ${ }^{3,4,5}$, Josep $M^{a}$ Alcañiz $^{3,4}$, and Albert Soler ${ }^{1}$ \\ ${ }^{1}$ Grup de Mineralogia Aplicada, Geoquímica i Geomicrobiologia, Departament de Mineralogia, \\ Petrologia i Geologia Aplicada, Facultat de Ciències de la Terra, Universitat de Barcelona (UB), \\ Martí i Franquès s/n, 08020, Barcelona, Spain \\ ${ }^{2}$ Serra Húnter Fellowship, Generalitat de Catalunya, Spain \\ ${ }^{3}$ CREAF, Cerdanyola del Vallès 08193, Spain \\ ${ }^{4}$ Universitat Autònoma de Barcelona, Cerdanyola del Vallès 08193, Spain \\ ${ }^{5}$ Centro de Investigación en Contaminación Ambiental (CICA), Universidad de Costa Rica (UCR), \\ San José, Costa Rica
}

\begin{abstract}
Increase of soil fertilization produces an increase of $\mathrm{N}$ exported to the hydrosphere. The amount of nitrate that reaches the aquifers is controlled by processes affecting $\mathrm{N}$-species within the soils. The most relevant processes are nitrification, denitrification, assimilation, mineralization, and immobilization. This work studies the fate of $\mathrm{N}$ compounds in soil after manure application in a lysimeter study. To this end the isotopic composition of $\mathrm{N}$ and $\mathrm{O}$ of dissolved nitrate $\left(\delta^{15} \mathrm{~N}^{-\mathrm{NO}_{3}}{ }^{-}\right.$ and $\delta^{18} \mathrm{O}-\mathrm{NO}_{3}{ }^{-}$) was studied coupled with the evolution of $\mathrm{N}$-compounds retained and leached from the soil. Results showed an increase in the $\delta^{15} \mathrm{~N}$ $\mathrm{NO}_{3}{ }^{-}$of the leached nitrate towards values similar to the $\delta^{15} \mathrm{~N}_{-} \mathrm{NH}_{4}{ }^{+}$from the applied manure. The highest $\delta^{15} \mathrm{~N}_{-} \mathrm{NO}_{3}{ }^{-}$values were measured after 100 days of manure application, and thereafter, values decreased progressively towards the initial $\delta^{15} \mathrm{~N}^{-\mathrm{NO}_{3}}{ }^{-}$of the soil before manure application.
\end{abstract}

\section{Introduction}

Nitrate $\left(\mathrm{NO}_{3}{ }^{-}\right)$is one of the most common water pollutants. $\mathrm{NO}_{3}{ }^{-}$contamination is originated mainly from diffuse (non-point) sources linked to intensive use of synthetic and organic fertilizers and livestock. Increasing use of fertilizers (synthetic and organic) is directly correlated with an increase of nitrate concentration in groundwaters. Previous studies have shown the long lag period between nitrate application to the soil and its discharge to surface and groundwaters, that has been estimated up to several decades $[1,2]$. The isotopic characterization of $\mathrm{N}$-compounds is a useful tool to understand processes

* Corresponding author: notero@ub.edu 
affecting $\mathrm{N}$ - compounds in soils. Processes such as nitrification, denitrification, plant assimilation and mineralization-immobilization-turnover (MIT) can modify the isotopic signal of $\mathrm{N}$ and $\mathrm{O}$ in nitrate, nitrite and ammonium in soils before these compounds are leached to the aquifers [3]. The significance of MIT processes has been reported to affect importantly the $\delta^{18} \mathrm{O}-\mathrm{NO}_{3}{ }^{-}$and limiting its application in nitrate apportionment studies [4]. To gain knowledge on the effect on the isotopic composition of $\mathrm{N}$ and $\mathrm{O}$ of $\mathrm{N}$-compounds through the processes occurring in the non-saturate zone, a lysimeter experiment was performed to evaluate the isotopic shifts produced in $\mathrm{N}$ and $\mathrm{O}$ in soils after fertilization with manure. The presence of high organic carbon in manure can favor the production of denitrification reactions. The aim of this work is to characterize isotopically $\mathrm{N}$ and $\mathrm{O}$ from nitrate, nitrite and ammonium retained and leached from soils after manure application.

\section{Methods}

\subsection{Experimental setup}

A lysimeter experiment was set up in a greenhouse at Torre Marimón (IRTA, Caldes de Montbui, Spain). Five lysimeters were constructed. The lysimeters were 48 x $20 \mathrm{~cm}$ tubes of polyvinyl chloride, with a perforated lid at the bottom and covered on the top with a 2 $\mathrm{mm}$ plastic mesh. The filling material of the lysimeters consisted on a $2 \mathrm{~cm}$ layer of rinsed quartz sand, to allow drainage, and a $40 \mathrm{~cm}$ layer of a nearby experimental agricultural soil, simulating A and B horizons, equivalent to $13.4 \mathrm{~kg}$ of soil. The soil used was obtained from an experimental field that had been fertilized with manure with a low $\mathrm{N}$ load $(50 \mathrm{~kg}$ $\mathrm{N} /$ ha year) during the last 6 years. The lysimeter experiments were installed on March $23^{\text {rd }}$, 2017 and the soil columns were left to stabilize for several days by an initial watering. On April $3^{\text {rd }}, 2017$, fifteen barley seeds (Hordeum vulgare) were sown, and each lysimeter was fertilized with $7.3 \mathrm{~g}$ of a thermally dried pig slurry. Five sampling surveys were carried out at relevant stages in relation to plant development and fertilization events (Table 1). An automatic watering was installed on each lysimeter to keep moisture below the maximum water holding capacity (around $20 \% \mathrm{w} / \mathrm{w}$ ).

Table 1. Experiment schedule.

\begin{tabular}{ccc}
\hline Sampling date & Days after setup & Sampling stage \\
\hline $3 / 4 / 2017$ & 11 & Pre-fertilization \\
\hline $5 / 4 / 2017$ & 13 & Post-fertilization \\
\hline $6 / 7 / 2017$ & 76 & Developed plant \\
\hline $5 / 7 / 2017$ & 104 & Harvest \\
\hline $4 / 12 / 2017$ & 256 & Bare soil \\
\hline
\end{tabular}

\subsection{Analytical methods}

In each lysimeter, soil, plant and water samples were collected. A $5.5 \times 7 \mathrm{~cm}$ core was used to collect topsoil in each lysimeter to prepare soil $\mathrm{KCl}$-extracts followed by a forced leaching. The $\mathrm{KCl}$ extracts were immediately prepared by weighting $20 \mathrm{~g}$ of soil and adding them to $100 \mathrm{ml}$ of $\mathrm{KCl} 2 \mathrm{M}(1: 5 \mathrm{v} / \mathrm{w})$, followed by a 30 min-period of shaking in a vertical agitator (120 rpm) (ISO/TS 14256-1: 2003). In parallel, water extracts were prepared using $40 \mathrm{~g}$ of soil in a 1:5 ratio $(\mathrm{v} / \mathrm{w})$. The $\mathrm{KCl}$ and water extracts were centrifuged $(5 \mathrm{~min}$ at $8000 \mathrm{rpm}$ ), filtered in Whatman no. 42 and frozen at $-20{ }^{\circ} \mathrm{C}$ for later determination of ion 
contents. For leachate collection, each lysimeter was placed on a glass tray but raised 1.3 $\mathrm{cm}$ to allow drainage. A suitable amount of water was added taking into account the water content at each lysimeter in order to collect around $200 \mathrm{ml}$ of leachate. The leachates were treated and analyzed as described for soil extracts. Plants were harvested at the end of their life cycle in summer. Shoots and leaves were dried at $60^{\circ} \mathrm{C}$ for $48 \mathrm{~h}$, and finely grounded. $\mathrm{N}$ content was obtained by near infrared spectrometry by scanning the grounded samples from 1,100 to $2,500 \mathrm{~nm}$ using a NIRSystems 5000 scanning monochromator. $\mathrm{NH}_{4}{ }^{+}$was measured using the salicylate method, in a Spectronic 20 Genesys 4001/4 spectrophotometer. The $\mathrm{NO}_{2}^{-}$and $\mathrm{NO}_{3}^{-}$concentrations were determined by ionic chromatography in an AS4A-SC Dionex anion column in a Dionex DX-100 Ion Chromatograph. The $\delta^{15} \mathrm{~N}$ and $\delta^{18} \mathrm{O}$ of dissolved $\mathrm{NO}_{3}{ }^{-}$were determined using a modified cadmium reduction method $[5,6]$. Simultaneous $\delta^{15} \mathrm{~N}$ and $\delta^{18} \mathrm{O}$ analysis of the $\mathrm{N}_{2} \mathrm{O}$ produced was carried out using a Pre-Con (Thermo Scientific) coupled to a Finnigan MAT253 Isotope Ratio Mass Spectrometer (Thermo Scientific). The $\delta^{15} \mathrm{~N}$ of dissolved $\mathrm{NH}_{4}{ }^{+}$was determined using the hypobromite method [7]. The $\delta^{15} \mathrm{~N}$ of manure applied as fertilizer was determined in a Carbo Erba EA-Finnigan Delta C IRMS.

\section{Results and discussion}

$\mathrm{NO}_{3}{ }^{-}$concentrations in $\mathrm{K}-\mathrm{Cl}$ extracts remained constant until the last sampling (day 245) when its concentration increased drastically (Fig. 1). This increase was likely produced because the last sample was collected 152 days after harvest and during this long period the system was not leached. $\mathrm{NO}_{2}^{-}$concentrations remained nearly constant along the experiment, ranging from below the detection limit to $0.3 \mathrm{mmol} / \mathrm{Kg}$-soil. Regarding $\mathrm{NH}_{4}{ }^{+}$, the highest values were observed in the first sampling after manure application reaching a maximum of $11.7 \mathrm{mmol} / \mathrm{Kg}$-soil. After this initial peak, values decreased down to 0.3 $\mathrm{mmol} / \mathrm{Kg}$-soil and remained constant (Fig. 1). Leachate from the soil showed higher variability between lysimeters with $\mathrm{NO}_{3}^{-}$concentration between 4.3 and $18.7 \mathrm{mM}$. In general, $\mathrm{NO}_{3}{ }^{-}$concentration decreased until day 100 , but the last sampling showed higher concentration. $\mathrm{NO}_{2}{ }^{-}$remained almost constant in all the lysimeters, with values around 0.01 , whereas $\mathrm{NH}_{4}{ }^{+}$showed concentration around $0.03 \mathrm{mM}$, but also increased sharply in the last sampling (up to $0.5 \mathrm{mM}$ ). The observed increase of $\mathrm{NO}_{3}{ }^{-}$and $\mathrm{NH}_{4}{ }^{+}$could be produced, as in the extracts, because of the long period with no leaching on the lysimeter and the absence of vegetation.

Fig. 2 shows the isotopic composition of manure, irrigation water, and harvested plants, together with the evolution of the all the lysimeters leachates and three of the $\mathrm{KCl}$ extracts. $\delta^{15} \mathrm{~N}$ and $\delta^{18} \mathrm{O}$ of $\mathrm{NO}_{3}{ }^{-}$in the soil extracts before manure application ranged between +6.3 $\%$ and $+4.7 \%$ for $\delta^{15} \mathrm{~N}$ and $+1.7 \%$ and $+10.5 \%$ for $\delta^{18} \mathrm{O}$. Regarding leached $\mathrm{NO}_{3}{ }^{-}$, the results of $\delta^{15} \mathrm{~N}$ ranged from $+4.6 \%$ and $+8.0 \%$ whereas $\delta^{18} \mathrm{O}$ showed values between +2.3 $\%$ and $+7.6 \%$. Once manure was applied and irrigation started, the isotopic composition of $\delta^{15} \mathrm{~N}$ increased in both, extracts and leachates. The highest values were measured after 93 days reaching $\delta^{15} \mathrm{~N}$ values higher than irrigation water but lower than manure. Regarding $\delta^{18} \mathrm{O}$ of nitrate a different evolution was observed in some lysimeters. One of them showed higher $\delta^{18} \mathrm{O}$ values in the extracts and leachate at day $93(+12.1 \%$ in soil extracts and $+10.1 \%$ in leachate), whereas for the other, values were lower ranging from +4.9 to +7.6 \%o (Fig. 2). Higher $\delta^{18} \mathrm{O}$ could be produced by a slight contribution of denitrification in the first lysimeter. Isotopic results showed that nitrate retained and leached during the first 100 days was mainly influenced by nitrification of manure and nitrate from irrigation producing an increase of $\delta^{15} \mathrm{~N}$ but maintaining the $\delta^{18} \mathrm{O}$ close to the initial values. The slightly higher 
$\delta^{15} \mathrm{~N}$ observed in soil extracts compared with leachate could be related with a higher influence of irrigation water in the leachate. After 245 days, the isotopic data of both the soil extract and the leachate decreased to values close to the initial isotopic composition. This evolution can be explained by a progressive decrease in the effect of fresh manure over the bulk $\mathrm{N}$ pool of the soil. As for the $\delta^{18} \mathrm{O}$, the narrow range observed is in agreement with nitrification as the main processes controlling the isotopic composition although a slight contribution of denitrification could not be discarded in some lysimeters.
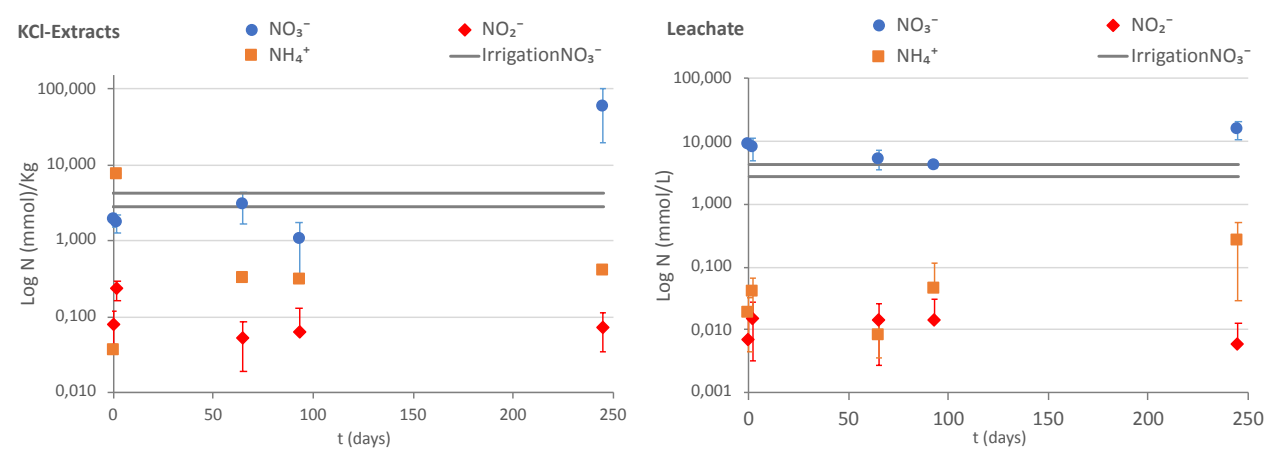

Fig. 1. Average concentration of $\mathrm{NO}_{3}{ }^{-}, \mathrm{NO}_{2}{ }^{-}$and $\mathrm{NH}_{4}{ }^{+}$retained in the soil ( $\mathrm{KCl}$ extracts, left) and leachate (right) along time.
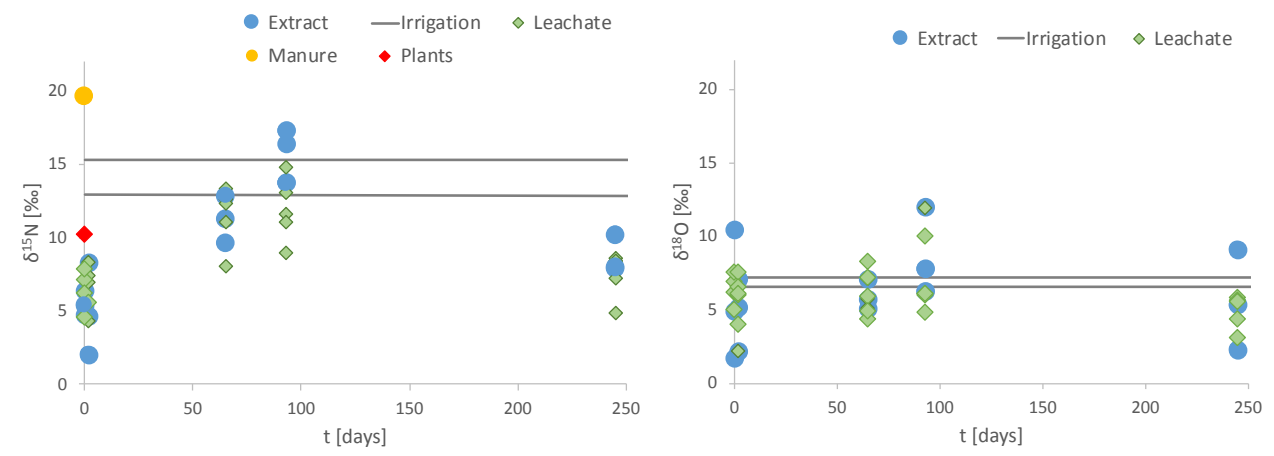

Fig. 2. $\delta^{15} \mathrm{~N}$ (left) and $\delta^{18} \mathrm{O}$ (right) of $\mathrm{NO}_{3}{ }^{-}$measured in $\mathrm{KCl}$ extracts and leachate. Manure, plant and irrigation values are also depicted.

\section{Conclusions}

Results show the effect of nitrification of $\mathrm{N}$ from fresh manure during the first 93 days. Denitrification was not significant, and only in one of the lysimeters the isotopic values suggest a limited effect. Samples collected 245 days after fertilization, showed that the leached nitrate had $\delta^{15} \mathrm{~N}$ and $\delta^{18} \mathrm{O}$ values similar to the initial values of the soil (before fertilization within the experimental period). This fact reflects that the initial N-pool in the soils was very important and masked the influence of the new applied $\mathrm{N}$.

This work has been financed by the following projects: PACE-ISOTEC (CGL2017-87216-C4-1-R) and FERTICHAR (AGL2015-70393-R) financed by the Spanish Government and AEI/FEDER from the UE, and MAG (2017-SGR-1733) from the Catalan Government. 


\section{References}

1. L. Wang, A.S. Butcher, M.E. Stuart, D.C. Gooddy, J.P. Bloomfield. Environ Geochem Health, 35: 667-681 (2013)

2. M. Sebilo, B. Mayer, B. Nicolardot, G. Pinay, A. Mariotti. Proceedings of the National Academy of Science of the United States of America, 110: 18185-18189 (2013)

3. M. Rivett, S. Buss, P. Morgan, J.W.N. Smith, C.D. Bemment. Water Research, 42: $\underline{4215-4232(2008)}$

4. M. Mengis, U. Walther, S.M. Bernasconi, B. Wehrli. Environmental Science and Technology, 35: 1840-1844 (2001)

5. M. R. McIlvin, M.A. Altabet. Analytical Chemistry, 77(3163): 5589-95 (2005)

6. E. Ryabenko, M.A. Altabet, D.W.R. Wallace. Limnology and Oceanography: Methods, 7: 545-52 (2009)

7. L. Zhang, M.A. Altabet, T. Wu, O. Hadas. Analytical Chemistry, 79(14): 5297-5303 (2007) 